\title{
Implication for Designing a REDD+ Program in a Frontier of Oil Palm Plantation Development: Evidence in East Kalimantan, Indonesia
}

\author{
Daisuke Terauchi', Ndan Imang2, Martinus Nanang2, Masayuki Kawai ${ }^{3}$, \\ Mustofa Agung Sardjono², Fadjar Pambudhi'2, Makoto Inoue ${ }^{3}$ \\ ${ }^{1}$ Department of Human Geography, Graduate School of Arts and Sciences, The University of Tokyo, Tokyo, \\ Japan \\ ${ }^{2}$ Center for Social Forestry, Mulawarman University, Samarinda, Indonesia \\ ${ }^{3}$ Department of Global Agricultural Sciences, Graduate School of Agricultural and Life Sciences, The University \\ of Tokyo, Tokyo, Japan \\ Email: aa087095@gmail.com
}

Received 17 February 2014; revised 21 March 2014; accepted 3 April 2014

Copyright (C) 2014 by authors and Scientific Research Publishing Inc.

This work is licensed under the Creative Commons Attribution International License (CC BY). http://creativecommons.org/licenses/by/4.0/

(c) (i) Open Access

\section{Abstract}

To examine the REDD+ (Reducing Emissions from Deforestation and Forest Degradation) program as an alternative to an oil palm plantation in West Kutai district of East Kalimantan, we determined the profitability of land use and REDD+, and the land use preferences and practices of the local people, as well as their participation in and preferences for forestry programs. Our findings indicate the following: 1) the profitability of an oil palm plantation was higher than that from other land uses and the REDD+ program; 2) the local preferences for land uses were mostly consistent with the profitability of the land uses, except for oil palm plantation due to non-financial concerns; 3 ) the local people combined each land use in accordance with their various needs; and 4) the local people were interested in a Forest and Land Rehabilitation (RHL) program in nonforestry zones. Considering these evidences, an improved RHL program based on an intensive agroforestry system and a conservation-based REDD+ program based on existing customary conservation forest management by the local people are proposed. Given the high opportunity cost and the low preference for an oil palm plantation, designing the REDD+ program by paying attention to the non-financial benefits for a community is a way forward. To enhance the non-financial benefits, it is important to take into consideration local preferences and livelihood activities in designing the REDD+ program. This study also implies the need for a reconsideration of the position of participation of local people in the safeguards of REDD+. 


\section{Keywords}

\section{REDD+, Oil Palm Plantation, Local People, Land Use Preference, Land Use Profitability}

\section{Introduction}

Developing countries are trying to introduce the REDD+ (Reducing Emissions from Deforestation and Forest Degradation) program, which is an incentive mechanism that provides carbon credit for activities designed to prevent deforestation and forest degradation. Actions that reduce the risk of biodiversity loss and increase respect for the rights of local people, as well as their full participation, should be promoted in the REDD+ program as safeguards (Jagger, Lawlor, Brockhaus, Gebara, Sonwa, \& Resosudarmo, 2012). Recent REDD+ articles indicate that REDD+ seeks to include more co-benefits, such as enhancing biodiversity conservation and alleviating poverty (Chhatre \& Agrawal, 2009; Venter, Meijaard, Possingham, Dennis, Sheil, Wich, Hovani, \& Wilson, 2009; Groom \& Palmer, 2012; Mustalahti, Bolin, Boyd, \& Paavola, 2012; Phelps, Friess, \& Webb, 2012). REDD+ is a policy framework in which three benefits (reducing carbon emissions, enhancing biodiversity conservation and alleviating poverty) can be discussed simultaneously. This paper does not use the word "co-benefit" but rather "triple-benefit" to emphasise the three benefits, which should be awarded equal attention, rather than placing primary attention on reducing carbon emissions while treating biodiversity and poverty alleviation as secondary issues (Inoue, 2010a; Inoue, 2012).

Although the REDD+ program has the potential to achieve "triple-benefits", the "REDD paradox (Sandbrook, Nelson, Adams, \& Agrawal, 2010)” still exists. The introduction of the REDD+ program creates incentives for recentralisation because of the rising forest values resulting from the carbon trading (Phelps, Webb, \& Agrawal, 2010; Sandbrook, Nelson, Adams, \& Agrawal, 2010). It is important to remember that historical deforestation and forest degradation was caused by the failure to manage national forests properly (Sandbrook, Nelson, Adams, \& Agrawal, 2010) and led to the exclusion of local people (Sikor, Stahl, Enters, Ribot, Singh, Sunderlin, \& Wollenberg, 2010). Thus, the REDD+ program must be designed to include the participation of the local people. It is also necessary to understand the trade-off and synergies between rural livelihood activities and REDD+ activities (Phelps, Webb, \& Agrawal, 2010). Only a few studies (Mustalahti, Bolin, Boyd, \& Paavola, 2012; Inoue, Kawai, Imang, Terauchi, Pambudhi, \& Sardjono, 2013) have examined the REDD+ program from the context of the livelihood activities and perceptions of the local people. Thus, the purpose of this paper is to examine the REDD+ program as a vehicle that can ensure "triple-benefit" and synergies with rural livelihood activities and the perceptions of local people based on evidence from East Kalimantan, Indonesia which has the most developed REDD legislation of the initial nine United Nations Collaborative Programme on Reducing Emissions from Deforestation and Forest Degradation in Developing Countries member countries (Mather, 2010).

Indonesian land is classified as "forestry zones (Kawasan Budidaya Kehutanan)" and "non-forestry zones (Kawasan Budidaya Non Kehutanan)” by law. Accordingly, $76 \%$ of land is identified as forestry zones and 24\% is identified as non-forestry zones. These classifications, however, doesn't reflect the land cover of the country. For example, in the non-forestry zones, there are landscapes rich in natural forests and agroforestry landscapes that have been developed for traditional land/forest uses by indigenous swiddeners. The development of oil palm plantations is permitted within "non-forestry zones".

The oil palm cultivation area in Indonesia has expanded rapidly from 673,033 ha in 1990 to 6,090,000 ha in 2011 (FAO, 2013). Koh \& Wilcove (2008) estimated that over 56\% of oil palm expansion between 1990 and 2005 occurred at the expense of primary, secondary, or plantation forest. The development frontier of oil palm plantation is moving from Sumatra to Kalimantan and Papua (Sheil, Casson, Meijaard, van Noordwijk, Gaskell, Sunderland-Groves, Wertz, \& Kanninen, 2009). In Kalimantan, the oil palm plantation area expanded from 90,300 ha in 1990 to 3,164,000 ha in 2010 in non-forestry zones. 90\% of this converted land was previously covered by forest (Carlson, Curran, Asner, Pittman, Trigg, \& Adeney, 2012). The development of oil palm plantation has been promoted by the Perusahaan Inti Rakyat (PIR) scheme in Indonesia, which is nucleus estate and smallholder scheme between companies and local people. The company establishes a mill and its own nucleus estate as well as smallholdings for participating villagers. The distribution rate of all oil palm plantation areas is 
less than $80 \%$ for the company estate and more than $20 \%$ for the village's plantation, which is distributed to each as 2 ha of oil palm plantation per participating villager. Recent articles have revealed that while oil palm development has improved income of local people (Zen, Barlow, \& Gondowarsito, 2006; Feintrenie, Chong, \& Levang, 2010; Kawai \& Inoue, 2010; Rist, Feintrenie, \& Levang, 2010), it has come at the expense of carbon stock and biodiversity (Butler, Koh, \& Ghazoul, 2009; Sheil, Casson, Meijaard, van Noordwijk, Gaskell, Sunderland-Groves, Wertz, \& Kanninen, 2009; Venter, Meijaard, Possingham, Dennis, Sheil, Wich, Hovani, \& Wilson, 2009).

The local people in East Kalimantan, which is a frontier of development for oil palm plantations, have two ways forward. If the local people choose huge oil palm plantations, they can expect drastic income improvements at the expense of carbon stock and biodiversity. Conversely, if local people choose traditional land uses, they cannot expect drastic income improvements even though carbon stocks and biodiversity will be, to some extent, sustained in an agroforestry landscape (Weinstock, 1983; Sardjono, 1990; Inoue, 1991; Gouyon, Foresta, \& Levang, 1993; de jong, 2001; Pambudhi, Belcher, Levang, \& Dewi, 2004). Considering this trade-off situation, it is worth examining REDD+, which has the potential to achieve the "triple-benefit" as a well-balanced development and conservation method as an alternative to maintaining traditional land use or to introducing oil palm development.

To examine the REDD+ program as a vehicle that can ensure "triple-benefit" and synergies with rural livelihood activities and perceptions of the local people in East Kalimantan, we set out three research objectives. The first objective is to examine the profitability of villagers' land uses and assess the financial potential of the REDD+ program in terms of profitability and equilibrium carbon price (ECP) on these land uses. For this objective, we conducted cost benefit analysis of land uses and the REDD+ program from the perspective of the villagers' land use decisions. It is important to analyse the opportunity cost, one of the evaluation methods of profitability, and the ECP from the villagers' land use decisions because the oil palm companies cannot legally exploit the land without the agreement of the village/villagers after the decentralisation and democratisation after 1999. But recent articles have analysed the opportunity cost and the ECP only from the perspective of the oil palm companies or the government (Butler, Koh, \& Ghazoul, 2009; Venter, Meijaard, Possingham, Dennis, Sheil, Wich, Hovani, \& Wilson, 2009; Fisher, Edward, Giam, \& Wilcove, 2011; Irawan, Tacconi, \& Ring, 2013). The second objective is to reveal the land use preferences and practices of local people. Local people may make land use decisions not only from a financial perspective but may also consider other factors. These findings will be essential for examining the REDD+ program, which has synergies with rural livelihood activities and the perceptions of local people. The third objective is to investigate local peoples' participation and preferences for existing forestry initiatives to design attractive REDD+ programs for the local people. The implications for the REDD+ program derived from evidence in East Kalimantan could be applied for other forested areas that are frontiers of oil palm plantation development, such as Papua province.

\section{Methods}

\subsection{Selection of Research Sites}

The world-wide famous tropical rainforest of Kalimantan, which is a store for significant carbon stock and home for rich biodiversity, is threatened by expanding of oil palm plantation (Carlson, Curran, Asner, Pittman, Trigg, \& Adeney, 2012; Venter, Meijaard, Possingham, Dennis, Sheil, Wich, Hovani, \& Wilson, 2009). The province of East Kalimantan is the centre of forest cover in Indonesia which is accounting for $11 \%$ of the national total (DK, 2008). West Kutai district, located in the province of East Kalimantan, was selected as the research site ${ }^{1}$. West Kutai district is located on the upper Mahakam River, which is one of the main rivers in East Kalimantan province. Due to one of the most inland district, the natural forests still remain, comparing other districts. The majority of population is Dayak people who is the indigenous people of Borneo Island and have survived on the resources derived from the forest.

In 2012, the oil palm plantations were already established in West Kutai district. That area occupied 3\% (24,195 ha) of the district's non-forestry zones (892,125 ha). Although there is a company's oil palm plantation and one mill downstream of the study area, a smallholder's plantation has not yet been established. The area that

\footnotetext{
${ }^{1}$ Since middle of 2013, East Kalimantan province has been divided into East Kalimantan province and North Kalimantan province and West Kutai district has been divided into West Kutai district and Mahakam Ulu district. In this paper, pre 2013 administrative boundary of East Kalimantan and West Kutai district is used.
} 
the oil palm company is attempting to acquire through government allocation occupies $74 \%$ (658,099 ha) of the district's non-forestry zones. Most of the residential and forest/land use area of the Dayak people located within district's non-forestry zones. Consequently, the area intended for oil palm development overlaps with the residential area of the Dayak people. Accordingly, the carbon stocks, biodiversity and livelihood of the Dayak people will be drastically changed. As a result, it is worth examining the "triple-benefit" of the REDD+ program in West Kutai district as an alternative to huge oil palm development.

Four villages that exhibited the aforementioned land use pressure, i.e. natural forest and agroforestry landscape threatened by oil palm conversion were selected for the study (Figure 1). In additions, the four villages are selected to represent the different ethnicities (a subgroup of Dayak people) of the study area as well as the level of difficulty in gaining access to the capital city of Samarinda. The villages include, ranked in order of their level of difficulty in accessing Samarinda, LT village (population 527), BM village (population 1052), BS village (population 1063), and SD village (population 1820). The ethnic majorities of the villages are as follows: the Bahau in LT village, the Kenyah in BM village, the Benuaq in BS village, and the Tonyoi (or Tunjung) in SD village. These study sites are the same as those in Inoue, Kawai, Imang, Terauchi, Pambudhi, \& Sardjono (2013). The major existing land uses in West Kutai district include swidden agriculture, traditional rubber gardens, project rubber plantations, rattan gardens, orchards and cacao gardens. These land uses can be observed in four villages. The local people do not have oil palm plantations.

\subsection{Cost Benefit Analysis of Land Uses}

The financial profitability consists of the "net present value (NPV)", the "benefit-cost ratio (B/C Ratio)", the "internal rate of return (IRR)", the "return to land" and the "return to labour". These all financial indicators are given for the existing land uses, including swidden agriculture, traditional rubber gardens, project rubber plantations, rattan gardens, orchards and cacao garden as well as oil palm plantations. Table 1 shows the description of each land use.

The data related to the cost and benefit of existing land uses were collected during 2010 and 2011. The number of respondents is shown in Table 2. With respect to the oil palm plantation, there were several types of development schemes. We clarified the profitability of PIR-PSM (PSM), PIR-KKPA (KKPA) and PIR-Swadaya (Swadaya) because these schemes will incorporate local people of West Kutai district into the production of palm oil. With respect to PSM and KKPA, three cases of profitability were analysed. The first is an average case,

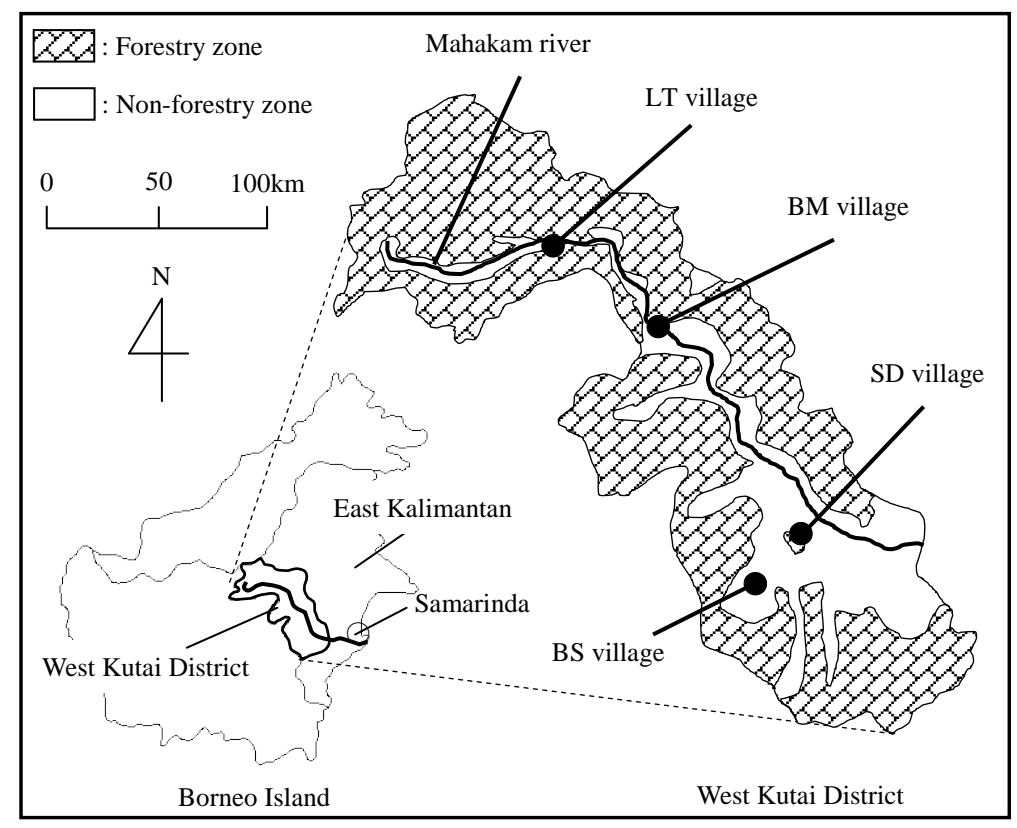

Figure 1. Map of research sites in the West Kutai district, province of East Kalimantan (Source: Created by authors based on Peta Peruntukkan Kawasan Kabupaten Kutai Barat Propinsi Kalimantan Timur). 
Table 1. Description of land uses in West Kutai district.

\begin{tabular}{|c|c|c|c|c|}
\hline \multirow{2}{*}{ Land use type } & \multirow{2}{*}{ Operations of management } & \multirow{2}{*}{$\begin{array}{l}\text { Price (IDR) } \\
\text { (Product) }\end{array}$} & \multicolumn{2}{|c|}{ Harvest } \\
\hline & & & First time & Interval \\
\hline Swidden agriculture & & $\begin{array}{l}7400 / \mathrm{kg} \\
\text { (Rice) }\end{array}$ & \multicolumn{2}{|c|}{ (Annual land use) } \\
\hline Rubber garden & $\begin{array}{l}\text { Operation of swidden agriculture consists of felling trees, drying in } \\
\text { the sun, burning, sowing, weeding, and harvesting rice. Villagers } \\
\text { plant seeds and seedlings of rubber, rattan, fruit trees and cacao to } \\
\text { develop gardens on the fallow after harvesting rice. They manage }\end{array}$ & $\begin{array}{l}\text { 8500/kg } \\
\text { (Rubber) }\end{array}$ & $6-7$ years & Everyday \\
\hline Rattan garden & $\begin{array}{l}\text { such gardens without using fertilizer and agrochemicals at all in the } \\
\text { production system. They intend to leave useful trees in the gardens, } \\
\text { which create agroforestry landscape and proved them various forest }\end{array}$ & $\begin{array}{l}\text { 1000/kg } \\
\text { (Rattan) }\end{array}$ & 8 - 10 years & 4 year $^{4}$ \\
\hline Orchard & $\begin{array}{l}\text { products. Old gardens can be used again as swidden to produce rice. } \\
\text { Swidden agriculture and tree crop production are well integrated as } \\
\text { long fallow swidden system. }\end{array}$ & \multicolumn{2}{|c|}{$\begin{array}{l}\text { Depending on } \\
\text { species (Fruit) }\end{array}$} & Every year \\
\hline Cacao garden & & $\begin{array}{l}12,000 / \mathrm{kg} \\
\text { (Cacao) }\end{array}$ & 4 - 5 years & Every week \\
\hline $\begin{array}{l}\text { Rubber plantation } \\
\text { (PRPTE/TCSSP) }^{2}\end{array}$ & $\begin{array}{l}\text { Department of agriculture of West Kutai District introduced programs } \\
\text { such as PRPTE in 1980's and TCSSP in 1990's. Under the programs, } \\
\text { villagers are granted improved variety of seedlings in the first year; } \\
\text { are loaned fertilizer, agrochemicals and maintenance cost during the } \\
\text { first six years. Mono-culture landscape is created. }\end{array}$ & $\begin{array}{l}\text { 8500/kg } \\
\text { (Rubber) }\end{array}$ & $6-7$ years & Everyday \\
\hline $\begin{array}{l}\text { Oil palm plantation } \\
\text { (PIR-KKPA) }^{3}\end{array}$ & $\begin{array}{l}\text { Villagers are expected to cooperate with enterprises under PIR-KKPA } \\
\text { and PIR-PSM schemes. The enterprise establishes and manages oil } \\
\text { palm plantations in inmature period. In PIR-KKPA, the enterprise }\end{array}$ & $\begin{array}{c}\text { 1205/kg } \\
\text { (Fresh Fruit }\end{array}$ & 4 years & \\
\hline $\begin{array}{l}\text { Oil palm plantation } \\
\text { (PIR-PSM) }^{3}\end{array}$ & $\begin{array}{l}\text { allocates each villager } 2 \text { ha of oil palm plantation which they can } \\
\text { manage by themselves in mature period. In PIR-PSM, the plantations } \\
\text { allocated to the villagers are managed by the enterprise; } 20 \% \text { of the } \\
\text { profits are distributed to the villagers, } 30 \% \text { to the bank as repayment }\end{array}$ & Bunch: FFB) & 4 years & 2 weeks \\
\hline $\begin{array}{l}\text { Oil palm plantation } \\
\text { (PIR-Swadaya) }^{3}\end{array}$ & $\begin{array}{l}\text { of loan, } 50 \% \text { to the enterprise as operation cost. In PIR-Swadaya, } \\
\text { villagers do not have to cooperate with company. They can be loaned } \\
\text { improved varieties of seedlings; be granted fertilizer and } \\
\text { agrochemicals from the project in the first two years. They manage } \\
\text { oil palm plantations by themselves. }\end{array}$ & $\begin{array}{l}811 / \mathrm{kg} \\
\text { (FFB) }\end{array}$ & 3 - 4 years & \\
\hline
\end{tabular}

\begin{abstract}
${ }^{1}$ The price of rice, fruits and cacao is for the research time while for rubber, rattan and FFB, is the average of the price between 2008 and 2011 . The prices of fruits in West Kutai district were as follows: Durian (Durio zibethinus) was IDR 15,000/piece, Cempedak (Artocarpus integer) was IDR 2500/piece, Rambutan (Nephelium sp.) was IDR 2000/bunch, Langsat (Lansium domesticum) was IDR 15,000/tin of $12 \mathrm{~kg}$, kwini (Mangifera caesia) was IDR 2000/kg and Kapul (Baccaurea macrocarpa) was IDR 2000/kg. The average price of FFB is based on Appendix 1. ${ }^{2}$ PRPTE stands for Peremajaan, Rehabilitasidan Perluasan Tanaman Ekspor (Rehabilitation and Expansion of Export Crops Program): TCSSP means Tree Crop Smallholder Sector Project. ${ }^{3}$ PIR stands for Perusahaan Inti Rakyat (Nucleus Estate Scheme): KKPA for Kredit Koperasi Primer untuk Anggota (Membership based Primary Cooperative Credit): PSM for Pola Satu Manajemen (One Management Scheme): Swadaya means Self-Reliance. The profit distribution rate of PSM is a tentative one offered by national oil palm company at Paser district in 2009. ${ }^{4}$ Though it needs four years to reproduce rattan cane, villagers harvest rattan cane in a garden little by little when they need money. (Source: Fieldwork).
\end{abstract}

Table 2. Number of respondents by land use types.

\begin{tabular}{|c|c|c|c|c|c|}
\hline \multirow{2}{*}{ Land use types } & \multicolumn{4}{|c|}{ Villages } & \multirow{2}{*}{ Total } \\
\hline & $\mathrm{LT}$ & $\mathrm{BM}$ & BS & SD & \\
\hline Swidden agriculture & 0 & 0 & 49 & 0 & 49 \\
\hline Traditional rubber garden & 0 & 2 & 4 & 4 & 10 \\
\hline Project rubber plantation & 0 & 0 & 0 & 10 & 10 \\
\hline Rattan garden & 7 & 0 & 14 & 0 & 21 \\
\hline Cacao garden & 0 & 10 & 0 & 0 & 10 \\
\hline Orchard & 0 & 0 & 4 & 6 & 10 \\
\hline
\end{tabular}

(Source: Fieldwork). 
which is based on the yield of the fresh fruit bunch (FFB) from the mineral soil of Kalimantan and the average transportation cost of the FFB. The second is the lowest case, which is based on the yield of FFB in infertile soil and the highest transportation cost. The third is the highest case, which is based on the yield of FFB in fertile soil and the lowest transportation cost. The data of the cost and benefit of the oil palm plantation are primarily based on the literature and on official documents, and they are partially based on field observations in Paser district, the centre of oil palm production in East Kalimantan ${ }^{2}$. Field observations in Paser district were conducted between July and August 2009.

According to the calculations, the discount rate is $10 \%$ over a 25 year period ${ }^{3}$. The wage rate for agricultural work in the villages of West Kutai district was IDR 50,000 per day (8 hours). The formulae for the NPV, B/C ratio, IRR, return to land, and return to labour are shown below. Bt denotes the benefit at year $t$, $\mathrm{C} t$ is the cost at year $t, t$ is time denoting year, $n$ is the management cycle, $i$ is the discount rate, $\mathrm{NPV}^{+}$is the accumulation of discounted positive cash flow, $\mathrm{NPV}^{-}$is the accumulation of discounted negative cash flow, $i_{1}$ is the first interest rate when NPV is positive, and $i_{2}$ is the first interest rate when NPV is negative.

\subsubsection{Net Present Value and Opportunity Cost}

Equation (1) is the formula used for calculation of the NPV.

$$
\mathrm{NPV}=\sum_{t=1}^{n} \frac{\mathrm{B} t-\mathrm{Ct}}{(1+i)^{t}}
$$

The NPV is the profitability of an investment in monetary terms, and this takes into account the risk of future profits, which are discounted by a specific percentage rate (10\%). If the NPV is greater than zero, the investment for land use is profitable. The opportunity cost is the difference in NPV between a chosen land use and one that is necessarily passed up. The opportunity cost between oil palm plantation and each existing land uses is equal to the NPV of oil palm plantation minus the NPV of each existing land use $\mathrm{A}^{4}$.

\subsubsection{Benefit-Cost Ratio}

Equation (2) is the formula used for calculation of the B/C ratio.

$$
\mathrm{B} / \mathrm{C} \text { ratio }=\left\{\sum_{t=1}^{n} \frac{\mathrm{B} t}{(1+i)^{t}}\right\} /\left\{\sum_{t=1}^{n} \frac{\mathrm{C} t}{(1+i)^{t}}\right\}
$$

If the $\mathrm{B} / \mathrm{C}$ ratio is greater than 1 , the benefit of the investment exceeds the cost of the investment.

\subsubsection{Internal Rate of Return}

Equation (3) is the formula used for calculation of the IRR.

$$
\mathrm{IRR}=i_{1} \frac{\mathrm{NPV}^{+}}{\mathrm{NPV}^{+}+\mathrm{NPV}^{-}}\left(i_{2}-i_{1}\right)
$$

IRR is the discount rate at which the NPV of the costs of the investment equals the NPV of the benefits of the investment. Therefore, if the IRR is greater than $10 \%$, the investment is profitable.

\subsubsection{Return to Land and Return to Labour}

The return to land is the average net added value generated by one hectare of land during 1 year, while the return

\footnotetext{
${ }^{2}$ There were independent oil palm smallholdings established and managed by local people without any kind of government support as well as oil palm plantations of PSM, KKPA and Swadaya in Paser district. We were unable to analyse that type of oil palm plantation, however, because of the limitations regarding literature and materials.

${ }^{3}$ Although White \& Minang (2011) proposed 5\% as the discount rate and 30 years as the timeframe based on the financial context of the REDD+ program, we adopted $10 \%$ and 25 years based on the context of the villagers' land use. The discount rate of $10 \%$ was adopted because most studies of the opportunity costs regarding land use of local people have been calculated with a 10\% discount rate (Grieg-Gran, 2008), and a 25-year timeframe is one production cycle of an oil palm plantation.

${ }^{4}$ The true concept of opportunity costs is not restricted to monetary or financial costs. The real cost of output forgone including environmental services, pleasure or any other benefits that provides utility should also be considered as opportunity costs. Our focus in this paper, however, is only financial opportunity costs as is in other previous studies like Belcher, Rujehan, Imang, \& Achdiawan (2009); Venter, Meijaard, Possingham, Dennis, Sheil, Wich, Hovani, \& Wilson (2009); Irawan, Tacconi, \& Ring (2013); Belcher, Rujehan, Imang, \& Achdiawan (2004); Sofiyuddin, Rahmanulloh, \& Suyanto (2012) and a training manual (White \& Minang, 2011).
} 
to labour is the return to land divided by the number of working days during 1 year (Feintrenie, Chong, \& Levang, 2010). The return to land and the return to labour do not take into account the risk of future profits.

\subsection{Cost Benefit Analysis of the REDD+ Program}

We were able to analyse the NPV and ECP of a conservation-based REDD+ program, which keeps natural forest from converting to oil palm plantations. However, we were unable to analyse the NPV and ECP of an agroforestry-based REDD+ program, which keeps an agroforestry landscape (existing land uses) from converting to oil palm plantations because it was difficult to define the size of the carbon stock in agroforestry. Various agroforestry landscapes exist.

Scenario analysis was applied for the cost benefit analysis of the REDD+ program. The first scenario is represented by the present condition where the Indonesian government does not consider oil palm plantations to be forests. The second scenario represents the potential condition where the Indonesian government does consider oil palm plantations to be forests. We considered both scenarios because there is a possibility that the Indonesian government will come to recognise oil palm plantations as forest to expand oil palm plantation while avoiding protests against deforestation by environmental $\mathrm{NGOs}^{5}$.

\subsubsection{Net Present Value of the REDD+ Program}

We employed equal allocation model of Butler, Koh, \& Ghazoul (2009), which he introduced to calculate NPV of the REDD+ program. Our variables of cost and benefit are same with those of Butler, Koh, \& Ghazoul (2009) except for the oil palm biomass carbon which we used 0 tons/ha for the first scenario and 88 tons/ha, for the second scenario based on Gibbs, Johnston, Foley, Holloway, Monfreda, Ramankutty, \& Zaks (2008). The annual appreciation of carbon financial instruments is fixed at $0.00 \%$ to ascertain the constant carbon price. The carbon price of US\$ 5.9/tCO $\mathrm{CO}_{2}$ is used based on Peters-Stanley \& Yin (2013) to represent the average carbon price in 2012.

Since the distribution rate of carbon credits among stakeholders must be considered to examine the profitability of REDD+ program from the perspective of local people, we assumed that the distribution rate averages $60 \%$ for local communities in the conservation-based REDD+ program with the highest rate being $70 \%$ and the lowest rate is $50 \%{ }^{6}$. Based on this assumption, three cases of NPV of REDD+ program were analysed.

\subsubsection{Equilibrium Carbon Price Offsetting the Opportunity Cost of Oil Palm Plantations}

The Annual Equivalent Value (AEV) is tool for measuring investment performances in land use of unequal time frame (Sasaki \& Yoshimoto, 2010). AEV of the PSM scheme of oil palm plantation and the conservation-based REDD+ program were calculated because PSM and REDD+ program have different timeframes, i.e., 25 years for PSM and 30 years for REDD+. We chose the PSM scheme because it has become the main development method for oil palm plantations after 2007 in Indonesia (DP, 2007). Equation (4) is the formula used for calculation of AEV.

$$
\mathrm{AEV}=\frac{\mathrm{NPV} \times i \times(1+i)^{n}}{(1+i)^{n+1}-1}
$$

where NPV is net present value, $i$ is the discount rate and $n$ is the management cycle.

ECP is the constant carbon price which makes AEV of conservation-based REDD+ program equalizing with AEV of PSM scheme of oil palm plantation. Based on the three cases of NPV of REDD+ program and the three cases of NPV of PSM, three cases of ECP, namely the average case based on average NPV of REDD+ program and average NPV of PSM, the high case based on low NPV of REDD+ program and high NPV of PSM and the low case based on high NPV of REDD+ program and low NPV of PSM in first and second scenarios, were analysed. If ECP is lower than US\$ 5.9/tCO 2 , REDD+ program can offset the opportunity cost of PSM scheme of

\footnotetext{
${ }^{5}$ Indeed, in April 2010, the Indonesian government announced that it had dropped its intention to designate oil palm plantations as forests in the face of protests by environmental NGOs (Inoue, 2010b).

${ }^{6}$ Given the aims of the conservation-based REDD+ program,we can infer that the distribution rate of carbon credits will be similar in all three REDD+ programs, namely the "Customary Forest (Hutan Adat)", the "Village Forest (Hutan Desa)" and the "Community Forest (Hutan Kemasyarakatan)". The distribution rate for local communities in the "Village Forest (Hutan Desa)" and "Community Forest (Hutan Kemasyarakatan)" programs is 50\%; in the "Customary Forest (Hutan Adat)" program, the rate is $70 \%$, as decreed in Appendix III of the Decree of the Minister of Forestry No. 36 in 2009.
} 
oil palm plantation and make profits.

\subsection{Villagers' Preferences and Practices with Respect to Land Use}

Villagers' preferences in the four villages regarding land use were revealed by arranging the data of Inoue, Kawai, Imang, Terauchi, Pambudhi, \& Sardjono $(2013)^{7}$. The practice of villagers' land use and the reason for the land use preferences were clarified by long-standing field research conducted in BS village for approximately one year between 2006 and 2012. The production of cacao is based on field observations in the villages of LT and BM because there are no cacao gardens in BS village.

\subsection{Participation and Preferences for Indonesian National Forestry Programs}

Six national forestry programs were selected to investigate the villagers' participation, preferences and constraining factors with respect to participation. The six programs include the "customary forest (Hutan Adat)", the "community-based forest plantations (Hutan Tanaman Rakyat)", the "community forest (Hutan Kemasyarakatan)", the "village forest (Hutan Desa)", the "private forest (Hutan Rakyat)" and the "forest and land rehabilitation (Rehabilitasi hutan dan lahan: RHL)" programs. The first five programs are selected because they are REDD+ programs and have high profit distribution rate for the local people identified by Inoue (2012) and Inoue, Kawai, Imang, Terauchi, Pambudhi, \& Sardjono (2013). The last program is selected because the local people can use and derive a profit from RHL even though it is not formally connected to REDD+ activity. Data were collected from the forestry service of West Kutai district and by way of interviews with 20 villagers as well as focus group discussions with 5 to 7 persons from each of the four study sites in October 2010.

\section{Results}

\subsection{Cost Benefit Analysis of Each Land Use and the REDD+ Program}

The financial profitability and characteristics of each land use are shown in Table 3. Judging from all financial indicators, especially focussing on NPV, we could conclude that three types of oil palm plantations had very high, traditional rubber gardens and project rubber plantations had high, and cacao gardens and orchards had medium financial profitability. Only rattan gardens were not profitable. The lowest NPV among the three types of oil palm plantation, i.e., that of Swadaya, was more than two times the NPV of traditional rubber gardens, which had the highest NPV among existing land uses. It could be concluded that the opportunity cost to keep existing land uses from converting to oil palm plantations was high.

The reasons for the very high NPV of the oil palm plantations were due to the high productivity per hectare and a short immaturity period. The ranking of high NPV among the three types of oil palm plantations was KKPA, PSM and Swadaya respectively. The reason for the highest NPV of KKPA was because of the high productivity per hectare despite the high loan repayment. Although PSM became the main national development scheme from 2007 onward, the NPV of PSM was lower than KKPA because the distribution rate (20\%) for villagers was low ${ }^{8}$. The reasons for the lower NPV and higher B/C ratio of Swadaya than those of KKPA were lower cost, especially with respect to the low repayment loan, and lower productivity per hectare than the KKPA. In traditional rubber gardens, the reason for the high NPV was because of the high price of rubber. In project rubber plantations, the reasons for the high NPV but low B/C ratio were because of the high amount of rubber per hectare derived from certified seedlings and intensive management and the high amount of the loan repayment. Cacao gardens reported a medium NPV. The low amount of cacao per hectare resulted in a lower NPV than both traditional and project rubber production although the price of cacao was high. With respect to orchards, the reasons for the medium NPV, high B/C ratio and high return to labour were due to the quite low physical and labour cost despite the low productivity per hectare. The NPV of rattan gardens was negative be-

\footnotetext{
${ }^{7}$ For a detailed explanation of the method, see Inoue, Kawai, Imang, Terauchi, Pambudhi, \& Sardjono (2013).

${ }^{8}$ We calculated the NPV of the KKPA and the PSM based on the same data of cost and benefit. Also, we assume the participating villagers in KKPA follow the company's technical guidelines and achieve performance levels equal to the companies. In such a case, the NPV of the KKPA and the PSM must be the same. A distribution rate of $41.5 \%$ for villagers, which will increase to $71.5 \%$ after the repayment of the loan, can achieve the same NPV of the PSM with the KKPA. Therefore, we can conclude that the present distribution rate for villagers (20\% is quite low, and for a company, $50 \%$ as operation cost is quite high. But it should be noted that the distribution rate of $41.5 \%$ for villagers changes depending on cost and benefit; in other words, it depends on the company's production strategy.
} 
cause of the low price of rattan cane and the long interval of reharvesting (4 years). Swidden agriculture was not profitable because the return to labour was lower than the standard wage rate (IDR 50,000/ha/man-day). The labour requirement of swidden agriculture was high.

The NPV of a conservation-based REDD+ program, which keeps natural forest from converting to oil palm plantations, in first and second scenarios is shown in Table 4. The profitability of the conservation-based REDD+ program in both the first and second scenarios was positive. The ECP in both the first and second scenarios, even in low case, was far higher than the recent carbon price (US\$5.9/tCO ${ }_{2}$ ). This means that it is quite difficult to offset the opportunity cost, which keeps natural forests from converting to oil palm plantations by carbon credits from the REDD+ program. Based on these evidences, it could be concluded that a conservation-based REDD+ program could give financial benefits for local people. However, the level of financial incentive was far lower than that of oil palm plantation.

\subsection{Villagers' Preferences and Practices for Each Land Use}

The villagers' preferences for the six existing land uses and the oil palm plantation are shown in Table 5. In all

Table 3. Financial profitability and characteristics by land use types ${ }^{1}$.

\begin{tabular}{|c|c|c|c|c|c|c|}
\hline $\begin{array}{l}\text { Land use } \\
\text { types }\end{array}$ & $\begin{array}{c}\text { NPV } \\
\text { (IDR 1000/ha) }\end{array}$ & $\mathrm{B} / \mathrm{C}$ ratio & $\begin{array}{c}\text { IRR } \\
(\%)\end{array}$ & $\begin{array}{l}\text { Return to land } \\
\text { (IDR 1000/ha/year) }\end{array}$ & $\begin{array}{c}\text { Return to labour } \\
\text { (IDR 1000/ha/man-day) }\end{array}$ & $\begin{array}{l}\text { Characteristics of } \\
\text { the land use }\end{array}$ \\
\hline $\begin{array}{l}\text { Oil palm } \\
\text { (KKPA) }\end{array}$ & $\begin{array}{l}68,831<99,844 \\
\quad<124,381\end{array}$ & $\begin{array}{l}1.78<2.29 \\
\quad<2.97\end{array}$ & - & 17,397 & 425 & $\begin{array}{l}\text { High productivity and short } \\
\text { immature period for oil palm; } \\
\text { Among three type, high loan }\end{array}$ \\
\hline $\begin{array}{l}\text { Oil palm } \\
\text { (PSM) }\end{array}$ & $\begin{array}{c}51,252<61,779 \\
<66,964\end{array}$ & - & - & 10,032 & - & $\begin{array}{l}\text { repayment and high } \\
\text { productivity in KKPA, low } \\
\text { distribution rate in PSM, }\end{array}$ \\
\hline $\begin{array}{l}\text { Oil palm } \\
\text { (Swadaya) }\end{array}$ & 48,479 & 3.56 & 296 & - & - & $\begin{array}{l}\text { low loan repayment and low } \\
\text { productivity in Swadaya }\end{array}$ \\
\hline $\begin{array}{l}\text { Traditional } \\
\text { rubber garden }\end{array}$ & 22,203 & 1.59 & 56 & 8588 & 87 & High price \\
\hline $\begin{array}{l}\text { Project rubber } \\
\text { plantation }\end{array}$ & 14,946 & 1.24 & - & 8110 & 78 & $\begin{array}{l}\text { High price, high productivity } \\
\text { and high loan repayment }\end{array}$ \\
\hline Cacao garden & 8959 & 1.36 & 41 & 4736 & 74 & High price and low productivity \\
\hline Orchard & 1902 & 1.38 & 22 & 801 & 121 & $\begin{array}{l}\text { Low productivity, low physical } \\
\text { and labour cost }\end{array}$ \\
\hline Rattan garden & -519 & 0.92 & 7 & 692 & 60 & $\begin{array}{l}\text { Low price and long interval of } \\
\text { reharvest }\end{array}$ \\
\hline $\begin{array}{l}\text { Swidden } \\
\text { agriculture }\end{array}$ & - & - & - & 2486 & 47 & High labour cost \\
\hline
\end{tabular}

${ }^{1}$ The authors applied an exchange rate in October 2012, US\$ 1 = IDR 9575. The authors could not estimate IRR of oil palm plantation (KKPA) due to no negative cash flow during the 25-year time frame; B/C ratio, IRR and return to labour of oil palm plantation (PSM) because of no cost; return to land and return to labour of oil palm plantation (Swadaya) due to limited data in the literature referred; IRR of project rubber plantation because of governmental support during the immature period; NPV, B/C ratio and IRR of swidden agriculture because of annual land use. ${ }^{2}$ For a detailed information of cost and benefit, see Appendix 2 and Appendix 3. (Source: Based on Appendixs 1-3).

Table 4. The results of cost benefit analysis of REDD+ program.

\begin{tabular}{ccccc}
\hline & Scenario & Low & Average & High \\
\hline \multirow{2}{*}{ NPV (IDR 1000/ha) } & First & 6138 & 7365 & 8593 \\
& Second & 3534 & 4241 & 4948 \\
ECP (US\$ $\left./ \mathrm{tCO}_{2}\right)$ & First & 34.0 & 47.7 & 61.9 \\
& Second & 55.9 & 78.3 & 101.6 \\
\hline
\end{tabular}

(Source: Fieldwork and based on Butler et al. (2009), Gibbs et al. (2008); Peters-Stanley and Yin (2013)). 
Table 5. Peoples’ preferences in terms of land use type.

\begin{tabular}{cccccc}
\hline \multicolumn{2}{c}{ Villages } & LT & BM & BS $^{1}$ & SD $^{1}$ \\
\hline & 1st & Swidden agriculture & Project rubber plantation & Traditional rubber garden & Project rubber plantation \\
2nd & Traditional rubber garden & Traditional rubber garden & Swidden agriculture & Traditional rubber garden \\
$\begin{array}{c}\text { Ranking } \\
\text { of the } \\
\text { preference }\end{array}$ & 3rd & Project rubber plantation & Cacao garden & Project rubber plantation & Swidden agriculture \\
& 5th & Cacao garden & Swidden agriculture & Orchard & Orchard \\
& 6th & Orchard & Orchard & Rattan garden & Oil palm plantation \\
& 7th & Oil palm plantation & Rattan garden & Oil palm plantation & Rattan garden \\
\hline
\end{tabular}

${ }^{1}$ There is no cacao garden in BS and SD villages. (Source: Arranged the data of Inoue et al. (2013)).

the four villages, the villagers' preference for swidden agriculture, traditional rubber gardens, and project rubber plantations were high, while they were only medium for cacao gardens and orchards and low for rattan gardens and oil palm plantations. Hence, difference in ethnicity and accessibility of capital city did not have any impact on land use preferences.

Regarding the villagers' preferences and profitability of land uses presented above, we clarified the land use practice and the reasons of preferences based on the evidence of BS village below.

Though swidden agriculture was not profitable, the villagers' preference for swidden agriculture was high. The villagers continued to practice swidden agriculture because they could produce food for one year and obtain customary land rights for gardens or plantations. Both the profitability and preferences for traditional rubber gardens were high. The villagers consider rubber production to be the primary daily cash income source because it draws a high profit, it is easy to harvest and transport the product, and it provides a regular (weekly) and long period (approximately 19 - 20 years) cash income source. As a result, the villagers were enthusiastic and eager to establish traditional rubber gardens. The profitability and preferences for the project rubber plantation was also high. The villagers realised high productivity during the harvesting period and wanted to use the government program for their rubber plantation. Some villagers did not adopt the project rubber plantation, however, because of constraints associated with government programs such as the complicated application procedures, constraints imposed to convert rubber plantation to other land uses, constraints on interculture use such as cassava and fruit trees, rigid regulations on implementation, repayment of loans and conflicts among villagers' operation groups. Both the profitability of and the preferences for the cacao gardens were medium. The villagers considered cacao gardens to be an additional source of cash income because the labour requirements were lower than those for rubber gardens, or they considered cacao gardens to be a bridging income source before they begin to actualise income from their rubber production because the immaturity periods of cacao gardens are shorter than those for rubber gardens. Both the profitability of and the preferences for orchards was medium. Villagers preferred fruits because of the taste, and accordingly, they established orchards in small parts of swidden fallows not for financial profit but for personal consumption. The profitability of rattan gardens was negative, and the preference for the rattan gardens was low. Villagers hesitated to harvest rattan as a regular cash income source and stopped establishing new rattan gardens because of its heavy labour requirement, especially to carry rattan cane, which weighs 30 to $40 \mathrm{~kg} /$ bundle. However, the villagers keep rattan gardens, not converting them to other gardens, and harvest rattan for making daily goods such as baskets. Also, the villagers harvest rattan in emergency periods, such as the illness of a family member, because the villagers can derive cash income from rattan gardens whenever they want, due to the stable price of rattan cane and the open harvest season.

While oil palm plantations had very high profitability, they were not highly preferred by the villagers. Actually, some villagers intended to accept the large scale development of oil palm plantations by a company in the customary forest of the upper river area ${ }^{9}$. The reasons were that it was difficult for villagers to use that area as swidden fields or tree gardens due to difficult access and that the villagers expected high profits of oil palm

\footnotetext{
${ }^{9} \mathrm{~A}$ customary forest as mentioned here is not a type of forestry program, and it does not comply with the official definition in the Forestry Act No.41, 1999; rather, it is the forest in the territory of each Dayak peoples’ village.
} 
plantations. However, almost villagers intended to reject the large scale development of the oil palm plantation by a company in available land use areas, such as near the village or near rivers and roads, where most of the lands have an agroforestry landscape and customary ownership by the villagers (Terauchi, Setsuda, \& Inoue, 2010). The villagers' mentioned three non-financial concerns and one financial concern as reasons for refusing ${ }^{10}$. The first non-financial concern they mentioned was the drastic change of lifestyle based on forest resources and high self-sufficiency caused by the development of a huge oil palm plantation. The second non-financial concern was the difficulty of keeping autonomy of the villagers. Their autonomy would be threatened with respect to the selection of shipments as well as constraints regarding the change of land use choice, interculture and rigid work regulations. The third non-financial concern was mental uneasiness. Mental uneasiness of villagers was caused by fear of high repayment loans, boycotting or cheating the price of the villagers' FFB, and a lack of understanding of the PIR scheme and a contract with a company regarding land rights. This mental uneasiness of the villagers was not based on financial considerations but on a fear of risk for their lives. The financial concern is the inequality of the land distribution system, which is $80 \%$ for company and $20 \%$ for villagers. Some villagers wanted to introduce oil palm plantation by themselves ${ }^{11}$. However, they thought that it was impossible because they do not have production materials, such as seeds/seedlings, agrochemicals and fertilisers, cultivation techniques and a market for FFB.

Based on our research results, we can conclude that most of villagers' preferences for land use are consistent with the profitability of land use. Our results partially confirm that financial return is a main driver in the villagers' land use decision-making (Feintrenie, Schwarze, \& Levang, 2010). However, the oil palm plantation was the exception. Villagers hesitated to introduce the oil palm plantation not only because they have not yet seen profits in prior to its introduction, but also because they have the persistent concern, mainly non-financial, about its introduction as described earlier. Villagers evaluated land use from not only financial aspect but also various non-financial aspects. And they combined each land use considering the merits and the demerits of each land use system, in other words, in accordance with various needs of their lives.

\subsection{Participations and Preference for Indonesian National Forestry Programs}

Different forestry programs were prepared in forestry zones and non-forestry zones. With respect to forestry zones, the local people could select "community-based forest plantations", "community forest", "village forest", "customary forest" and one of the RHL programs which is "reforestation in protected forests (Reboisasi)". The first three programs have not, as yet, been implemented in any village in West Kutai district. Villagers were not interested in these three programs because they did not know the details regarding these three national programs. The "customary forest" program cannot be implemented because a minister's decree has not yet been issued to guide the formalities for approval (Inoue, Kawai, Imang, Terauchi, Pambudhi, \& Sardjono, 2013). Interestingly, villagers were, to some extent, interested in the "reforestation in protected forests" program, and the program was implemented (Table 6). However, it should be noted that only 910 ha were allotted to the villagers, while 1580 ha were allotted to the company.

With respect to the non-forestry zones, local people could select "private forest" and select from among four types of RHL programs. There was no example of "private forest" in East Kalimantan because it is difficult for villagers to obtain the formal land certification needed to apply for "private forest" (Inoue, 2012). Four types of RHL included "community gardens (Hutan Rakyat Pola Kebun)", "pure private forest (Hutan Rakyat Murni)", "interculture of timber with non-perennial crops (Hutan Rakyat Tumpang Sari)", and "miscellaneous forestry-based business (Aneka Usaha Kehutanan)" such as non-timber forest products. Villagers were interested in four types of RHL programs. "Community gardens", especially rubber plantations, are the most popular (Table 6). However, lack of information regarding the program and its application procedures, insufficient technical supports and grants from the government, and a conflict of interest concerning the use of subsidies among villagers' operation groups were mentioned by villagers as constraints for participation in RHL programs.

Based on the above results of the local peoples' participation and preference for the national forestry program, it is possible and efficient to improve the RHL program, especially the "community garden" rubber plantation, under the REDD+ program. To obtain more local participation, the removal of the constraints mentioned above

\footnotetext{
${ }^{10}$ We defined the financial concerns are the concerns that local people associated with cost and benefit in monetary term while non-financial concerns covers all the other concerns.

${ }^{11}$ PIR-Swadaya has not yet been prepared in West Kutai district. Also, villagers did not know the PIR-Swadaya scheme.
} 
Table 6. Total area of forest and land rehabilitation program during 2002-2008.

\begin{tabular}{ccccc}
\hline Forestry zones & & Non-forestry zones & \\
\hline Reforestation & Community garden & Pure private forest & $\begin{array}{c}\text { Intercropping of timber with } \\
\text { non-perennial crops }\end{array}$ & $\begin{array}{c}\text { Miscellaneous forestry-based } \\
\text { business }\end{array}$ \\
2490 ha & 16,611 ha & 3160 ha & 800 ha & 8383 ha \\
\hline
\end{tabular}

(Source: Fieldwork).

is required.

\section{Discussion}

After discussing the possibility of achieving "triple-benefit" with oil palm plantations, a REDD+ program that can ensure "triple-benefit" and synergies with rural livelihood activities and perception of local people is discussed in this section based on our findings mentioned above.

\subsection{The Possibility of Achieving "Triple-Benefit" with Oil Palm Plantations}

It is inferred that oil palm plantation established by Swadaya or villagers themselves have the potential to be combined with existing land uses and to improve income over avoiding non-financial concerns along with huge oil palm development such as KKPA and PSM. However, the constraint is that the FFB must be processed in a mill within 48 hours to maintain the quality of the crude palm oil (Sheil, Casson, Meijaard, van Noordwijk, Gaskell, Sunderland-Groves, Wertz, \& Kanninen, 2009; Feintrenie, Chong, \& Levang, 2010). Therefore, it is necessary for villagers in West Kutai district to collaborate with a company that has enough capital to establish the necessary mill and roads at the beginning of the development of oil palm plantation. Accordingly, oil palm companies need huge plantation areas to recover that investment, which is more than 4000 ha (Wakker, 2005; Sheil, Casson, Meijaard, van Noordwijk, Gaskell, Sunderland-Groves, Wertz, \& Kanninen, 2009). There is one mill in the downstream area in West Kutai district. However, villagers do not have a way of transporting FFB there. Therefore, reducing carbon stock, biodiversity loss, embracing the aforementioned non-financial concerns by large scale development are inevitable in West Kutai district.

Given the financial profits, the carbon stock and villagers' preferences for interculture, agroforestry would be a preferable land use option. Agroforestry that combined oil palm with teaks or several other fruit trees has been implemented by the district forestry service and by the local people in Paser district, but they did not obtain the desired synergic financial profits between oil palm and other trees (Terauchi, 2011).

Precise landscape planning at the district level that designs exploitation areas and conservation areas has the potential to mitigate the loss of carbon stock and biodiversity and enhance the local economy. However, the high potential risk of customary land expropriation still exists. The villagers were afraid that the land might not be returned to them, although they did not mention this fear based on the following legal framework. After the expiration of the land exploitation rights (Hak Guna Usaha), which are issued for the company estate by the National Land Tenure Board (Badan Pertanahan National), the land rights are then "returned to the nation" (Kawai \& Inoue, 2010; Kawai, 2011) ${ }^{12}$. Despite having "less than” $80 \%$, the village must provide a huge area of customary land/forest for the company estate in KKPA and PSM. According to the National Land Tenure Board, "returned to the nation" means that the district government can make decisions as to how to use the land because the district government has the right to manage non-forestry zones after decentralisation. Although there is the possibility that the district government will return the land rights to the village/villagers, this possibility is low. The reason is that the district government is more likely to prefer attracting investment (company) to enhance the local economy and gain popularity with the electorate (Irawan, Tacconi, \& Ring, 2013). There is no risk of land expropriation in oil palm development by Swadaya or villagers themselves. However, it is impossible for the villagers in West Kutai district to introduce oil palm plantation without a company mill as mentioned above.

Judging from discussion above, it is inferred that it is difficult for villagers in West Kutai district to achieve "triple-benefit" by oil palm plantation and avoid non-financial concerns due to the biological characteristics of FFB, the technical issues related to agroforestry and the legal framework of land tenure.

\footnotetext{
${ }^{12}$ This is mentioned in articles 4 and 18 of the government decree of the Republic of Indonesia No. 40 in 1996.
} 


\subsection{The Possibility of Achieving "Triple-Benefit" by Implementing the REDD+ Program}

Given the high profitability of an oil palm plantation and the recent low carbon price (US\$ 5.9/tCO ${ }_{2}$ ), it is most likely difficult to offset the opportunity cost, which keep natural forest or the agroforestry landscape from converting to oil palm plantation, by the carbon credits of the REDD+ program. However, given the villagers' low preference for an oil palm plantation due to mainly non-financial concerns and the villagers' land use practices, which combine several land uses to meet their various needs, it is advisable that the REDD+ program be designed by paying attention to non-financial aspects including meeting various needs of their lives and avoiding the non-financial concerns for oil palm plantation as well as financial aspects, such as profitability of land uses and carbon credit, to compete with oil palm plantations. What type of REDD+ program achieves the "triplebenefit” and meets the non-financial benefits?

\subsubsection{Implications for the REDD+ Program in Available Land Use Areas of Non-Forestry Zones}

In available land use areas where there exists an agroforestry landscape, it is possible and efficient to improve the RHL program, especially the "community garden” rubber plantations, under the REDD+ program, given the results of the villagers' participation in the national forestry program. Based on the results on the constraints of participation in the RHL program and the shortcomings of the project rubber plantation with respect to villagers' preferences, the following improvements will promote villager participation: 1) the simplification of the application procedure; 2) the adoption of partial support by grants, as in the RHL, rather than full support by loans, as in rubber plantation projects and the expansion of grants; and 3) the expansion of human resources to include collaborations with the government and NGOs to convey precise information, to assist with the application procedure and to provide advice on farming technique and on conflicts among groups in the villages.

An intensive agroforestry system that combines several certified trees and crop species that are planted at optimum and regular distances from each other, not a plantation system such as community garden programs or traditional garden systems, is suggested for adoption in the RHL programs. Villagers preferred land uses that have high financial returns and noted the constraints on interculture with respect to oil palm and rubber plantations as a shortcoming. It is inferred that the intensive agroforestry system is in line with villagers' preference. In addition, Penot (2004) reported that the rubber agroforestry system, which combines certified rubber trees with other useful trees and crops, had a higher NPV than a rubber plantation as well as providing biodiversity benefits and adapting to market fluctuations. Judging from the above evidence, it is effective to adopt an intensive agroforestry system to achieve the "triple-benefit" and meet the various needs of the villagers. The remaining issues are to identify the several synergy combination models among trees and crops, not only rubber agroforestry but also other types of agroforestry and to find the optimal input and output of the cultivation system. These issues should be examined using the participatory approach to reflect villagers' preferences for model. Thus, it is inferred that an improved RHL program has the potential to increase cash income and meet the various non-financial benefits. In addition, carbon stock and biodiversity levels will be maintained to some extent in the agroforestry landscape, rather than oil palm plantation.

\subsubsection{Implications for the REDD+ Program in Customary Forest Area of Non-Forestry Zones}

Some villagers in BS village intended to accept the oil palm development in the customary forest of the upper river area. Moreover, the oil palm companies were willing to develop plantations in the area because they expected profit from timber, which would be derived upon clearing the forest. The companies also wanted to avoid the costs of negotiation and compensation to the customary landowner that are needed in available land use areas. It is suggested that a conservation-based REDD+ program needs to be prepared in the customary forest of the upper river area to provide financial incentives for conservation although there is no conservation-based forestry program for non-forestry zones. Based on the result of NPV and ECP of a conservation-based REDD+ program and considering recent carbon price (US\$ 5.9/tCO ${ }_{2}$ ), a conservation-based REDD+ program could give financial benefits for local people. However, the level of financial incentive was far lower than that of oil palm plantation. This comparison, nonetheless, is without including vital forest ecosystem services, such as non-timber forest products, erosion control, water services etc., which are next to impossible evaluate them in monetary term.

Villagers in LT village opposed the introduction of oil palm development to customary forest. The LT villagers decided, instead, to manage their land as a customary conservation forest. The customary conservation forests, referred to as Tana' Pera' in Bahau people of LT villages, allow the villagers to harvest non-timber forest 
products and timber for public uses or in emergency periods with the approval of the village, but they are prohibited from developing swidden fields and gardens. This is a traditional management method for customary conservation forest, which is common in Bahau villages. Villages of Kenyah people, including BM village, also have customary conservation forests called Tana' Ulen, like the LT village of the Bahau people. They recognise that the benefits of Tana' Ulen are to provide good environmental services such as drinking water reservoirs, recreation and beautiful landscapes as well as to provide forest products (Imang, Inoue, \& Sardjono, 2009).

Judging from these discussions, the conservation-based REDD+ program should be attractive to the villagers from the non-financial perspective including environmental services as well as the financial (carbon credit) perspective. Customary conservation forest management methods such as Tana' Pera' and Tana' Ulen are useful examples to consider when designing a conservation-based REDD+ program. It is further inferred and suggested that a conservation-based REDD+ program be designed according to the participatory approach.

\section{Conclusions and Policy Implications}

This paper aimed to contribute to designing REDD+ program that can ensure the "triple-benefits" and synergies with rural livelihood activities and perceptions of local people in areas that are frontier of oil palm plantation development. We determined the profitability of land use and the REDD+ program, the land use preferences and practices of local people, and the local peoples' participation in and preferences for the forestry program in West Kutai district of East Kalimantan. Our findings reveal that 1) the profitability of oil palm plantations was higher than that for all other land uses and the REDD+ program, 2) the villagers' preferences for land use were mostly consistent with the profitability of land use while oil palm plantations were not preferred due to mainly non-financial concerns, 3) the villagers combined each land use in accordance with their various needs and 4) the villagers were interested in the RHL program.

Considering these findings, we propose an improved RHL program based on an intensive agroforestry system as the REDD+ program for available land use areas. In addition, a conservation-based REDD+ program that considers the existing customary conservation forest management by the local people is needed in the customary forest of the upper river area because the possibility of oil palm development is high. Given the high opportunity cost of oil palm plantations as well as the important role that non-financial considerations play in local peoples' land use decision-making, designing the REDD+ program by paying attention not only to financial benefits, but also for non-financial benefits to the community is a way to forward. This implication would be applicable for other areas that are a frontier of oil palm plantation development such as Papua province.

It is also recommended to broaden the definition of "alleviating poverty" which is one component of the "triple-benefit” (Inoue, 2010a; Inoue, 2012) from solely concentrating on financial benefit to encompassing nonfinancial benefits to community. To enhance the non-financial benefits, it is necessary to secure participation of local people in decision making in order to take into account local people's preferences and their livelihood activities when designing the REDD+ programs. The participation of the local people are specified in the REDD+ safeguards with non-binding targets, which should be "promoted" or "supported" when undertaking the REDD+ program. It is inferred that the reason why targets should not be "ensured" but "promoted" or "supported" is that there is a concern for REDD+ program implementation to become more complicated and difficult due to ensuring the participation approach. However, we assert that "ensuring" the participation approach, which means the ensuring non-financial benefit to community "promotes" and "supports" the REDD+ program in the frontier of oil palm plantation development in Indonesia.

\section{Acknowledgements}

The authors thank the key informants and the many respondents in the villages and the staff of the Center for Social Forestry at Mulawarman University, Indonesia. We gratefully acknowledge the financial support of the Environment Research and Technology Development Fund (D-1005, headed by Professor Toshinori Okuda, Hiroshima University) of the Ministry of the Environment, Japan.

\section{References}

Belcher, B., Rujehan, Imang, N., \& Achdiawan, R. (2004). Rattan, Rubber, or Oil Palm: Cultural and Financial Considerations for Farmers in Kalimantan. Economic Botany, 58, 77-87. http://dx.doi.org/10.1663/0013-0001(2004)58[77:RROOPC]2.0.CO;2 
Butler, R. R., Koh, L. P., \& Ghazoul, J. (2009). REDD in the Red: Palm Oil Could Undermine Carbon Payment Schemes. Conservation Letter, 2, 67-73. http://dx.doi.org/10.1111/j.1755-263X.2009.00047.x

Carlson, K. M., Curran, L. M., Asner, G. P., Pittman, A. M., Trigg, S. N., \& Adeney, J. M. (2012). Carbon Emissions from Forest Conversion by Kalimantan Oil Palm Plantation.Nature Climate Change, 3, 283-287. http://dx.doi.org/10.1038/nclimate1702

Chhatre, A., \& Agrawal, A. (2009). Trade-Offs and Synergies between Carbon Storage and Livelihood Benefits from Forest Commons.Proceedings of the National Academy of Sciences of the United State of America, 106, 17667-17670. http://dx.doi.org/10.1073/pnas.0905308106

de jong, W. (2001). The Impact of Rubber on the Forest Landscape in Borneo.In A. Angelsen, \& D. Kaimowitz (Eds.), Agricultural Technologies and Tropical Deforestation (pp. 367-381).Wallingford, UK: CABI Publishing.

http://www.cifor.org/publications/pdf_files/Books/CDeJong0101E0.pdf

DK (Departemen Kehutanan) (2008) Statistik Kehutanan Indonesia Tahun 2008. Jakarta: Departemen Kehutanan.

DP (Departemen Pertanian) (2007) Program Revitalisasi Perkebunan (Kelapa Sawit, Karet dan Kakao). Jakarta: DirektoratJenderal Perkebunan.

DPPKT (Dinas Perkebunan Provinsi Kalimantan Timur) (2014). Perkembangan Harga Komoditi Perkebunan: RekapitulasiHarga TBS Kelapa Sawit Tahun 2008-2011.

http://disbun.kaltimprov.go.id/statis-83-perkembangan-harga-komoditi-perkebunan.html

FAO (2013). FAOSTAT Online Statistical Service. http://faostat3.fao.org/home/index.html\#DOWNLOAD

Feintrenie, L., Chong, W. K., \& Levang, P. (2010). Why do Farmers Prefer Oil Palm? Lessons Learnt from Bungo District, Indonesia. Small-scale Forestry, 9, 379-396. http://dx.doi.org/10.1007/s11842-010-9122-2

Feintrenie, L., Schwarze, S., \& Levang, P. (2010). Are Local People Conservationists? Analysis of Transition Dynamics from Agroforests to Monoculture Plantations in Indonesia. Ecology and Society, 15, 37. http://www.ecologyandsociety.org/vol15/iss4/art37/

Fisher, B., Edward, D. P., Giam, X., \& Wilcove, D. S. (2011). The High Costs of Conserving Southeast Asia’s Lowland Rainforest. Frontiers in Ecology and the Environment, 9, 329-334. http://dx.doi.org/10.1890/100079

Gibbs, H. K., Johnston, M., Foley, J. A., Holloway, T., Monfreda, C., Ramankutty, N., et al. (2008). Carbon Payback Times for Crop-based Biofuel Expansion in the Tropics: The Effects of Changing Yield and Technology. Environmental Research Letters, 3, 1-10. http://dx.doi.org/10.1088/1748-9326/3/3/034001

Gouyon, A., Foresta, H., \& Levang, P. (1993). Does “Jungle Rubber” Deserve Its Name? An Analysis of Rubber Agroforestry Systems in Southeast Sumatra. Agroforestry System, 22, 181-200. http://dx.doi.org/10.1007/BF00705233

Grieg-Gran, M. (2008). The Cost of Avoiding Deforestation: Update of the Report Prepared for the Stern Review of the Economics of Climate Change. International Institute for Environment and Development. http://pubs.iied.org/pdfs/G02489.pdf

Groom, B., \& Palmer, C. (2012). REDD+ and Rural Livelihoods. Biological Conservation, 154, 42-52. http://dx.doi.org/10.1016/j.biocon.2012.03.002

Imang, N., Inoue, M., \& Sardjono, M. A. (2009). Importance of Boundaries in Customary Resource Management under Decentralized Policies: Case Study in Indigenous Kenyah Dayak, East Kalimantan, Indonesia. Journal of Forest Economics, $55,35-43$.

Inoue, M. (1991). Swidden-Rattan Production System in East Kalimantan, Indonesia. Journal of Forest Economics, 119, 4350.

Inoue, M. (2010a). Appropriate Incentive Distribution Mechanisms under Emerging REDD-Plus Regime: Focusing on Triple-Benefit and Legitimacy. Research on Environmental Disruption, 40, 16-22.

Inoue, M. (2010b). Environment and Development: Risks of Overemphasis on $\mathrm{CO}_{2}$ Reduction. http://www.asahi.com/shimbun/aan/english/hatsu/eng_hatsu100602.html

Inoue, M. (2012). Simple Method for the Local Stakeholders to Evaluate and Select National REDD-Plus Program: A Case Study of Indonesia. Journal of Forest Science, 28, 194-198. http://dx.doi.org/10.7747/JFS.2012.28.3.194

Inoue, M., Kawai, M., Imang, N., Terauchi, D., Pambudhi, F., \& Sardjono, M. A. (2013). Implications of Local Peoples’ Preferences in Terms of Income Source and Land Use for Indonesia's National REDD-Plus Policy: Evidence in East Kalimantan, Indonesia. International Journal of Environment and Sustainable Development, 12, 244-263. http://dx.doi.org/10.1504/IJESD.2013.054951

Irawan, S., Tacconi, L., \& Ring, I. (2013). Stakeholders’ Incentives for Land-Use Change and REDD+: The Case of Indonesia. Ecological Economics, 87, 75-83. http://dx.doi.org/10.1016/j.ecolecon.2012.12.018

Jagger, P., Lawlor, K., Brockhaus, M., Gebara, M. F., Sonwa, D. J., \& Resosudarmo, I. A. P. (2012). REDD+ Safeguards in 
National Policy Discourse and Pilot Projects. In A. Angelsen, M. Brockhaus, W. D. Sunderlin, \& L. V. Verchot (Eds.), Analysing REDD+: Challenges and Choices (pp. 301-316). Bogor: Center for International Forestry Research. http://www.cifor.org/publications/pdf_files/Books/BAngelsen120117.pdf

Kawai, M., \& Inoue, M. (2010). Possibility of Moderate Industrialization as Alternative Development Strategy to Oil Palm Plantation: The Case of Middle-Upper Mahakam Region in East Kalimantan, Indonesia. Forest Economy, 63, 1-17.

Kawai, M. (2011). “Moderate Industrialization” and Commons: Alternative Development Strategy to Oil Palm Plantation in East Kalimantan, Indonesia. Proceedings of the 13th Biennial Conference of the International Association for the Study of the Commons (IASC). http://iasc2011.fes.org.in/papers/docs/432/submission/original/432.pdf

Koh, L. P., \& Wilcove, D. S. (2008). Is Oil Palm Agriculture Really Destroying Tropical Biodiversity? Conservation Letters, 1, 60-64. http://dx.doi.org/10.1111/j.1755-263X.2008.00011.x

KP (Kementerian Pertanian) (2010). Pembangunan Kebun Sawit Rakyat PIR-Swadaya di Kaltim. Mediaperkebunan, 83, 1213.

Mather, R. (Ed.) (2010). Preparing REDD in Viet Nam, Lao PDR and Cambodia: Designing a REDD-Compliant Benefit Distribution System. Bangkok: IUCN Asia Regional Office. http://data.iucn.org/dbtw-wpd/edocs/2010-082.pdf

Mustalahti, I., Bolin, A., Boyd, E., \& Paavola, J. (2012). Can REDD+ Reconcile Local Priorities and Needs with Global Mitigation Benefits? Lessons from Angai Forest, Tanzania. Ecology and Society, 17, Article No. 16. http://dx.doi.org/10.5751/ES-04498-170116

Pahan, I. (2010). Panduan Lengkap Kelapa Sawit: Manajemen Agribisinis dari Hulu hingga Hilir. Jakarta: Penebar Swadaya.

Pambudhi, F., Belcher, B., Levang, P., \& Dewi, S. (2004). Rattan (Calamus spp.) Gardens of Kalimantan: Resilience and Evolution in a Managed Non-Timber Forest Product System. In K. Kustersand \& B. Belcher (Eds.), Forest Products, Livelihoods and Conservation-Case Studies of Non-Timber Forest Product Systems (pp. 347-365) Vol.1-ASIA. Bogor: Center for International Forestry Research.

http://www.cifor.org/online-library/browse/view-publication/publication/1481.html

Penot, E. (2004). From Shifting Agriculture to Sustainable Complex Rubber Agroforestry Systems (Jungle Rubber) in Indonesia: A History of Innovation Processes. In D. Babin (Ed.), Beyond Tropical Deforestation from Tropical Deforestation to Forest Cover Dynamics and Forest Development (pp. 221-250). Paris: The United Nations Educational, Scientific and Cultural Organization(UNESCO) and the Centre de coopération internationale en recherche agronomique pour le développement (CIRAD).

http://hal.archives-ouvertes.fr/docs/00/17/33/02/PDF/BOOK_CHAPTER_unesco_2003_af_pENOT.pdf

Peters-Stanley, M., \& Yin, D. (2013). Maneuvering the Mosaic: State of the Voluntary Carbon Markets 2013, 1. Market Overview: Volume and Value. Ecosystem Marketplace a Forest Trends Initiative and Bloomberg New Energy Finance.

http://www.forest-trends.org/documents/files/doc_3935.pdf

Phelps, J., Friess, D. A., \& Webb, E. L. (2012). Win-Win REDD+ Approaches Belie Carbon-Biodiversity Trade-Offs. Biological Conservation, 154, 53-60.http://dx.doi.org/10.1016/j.biocon.2011.12.031

Phelps, J., Webb, E. L., \& Agrawal, A. (2010). Does REDD+ Threaten to Recentralize Forest Governance? Science, 16, 312-313. http://www.rightsandresources.org/documents/files/doc 1461.pdf http://dx.doi.org/10.1126/science.1187774

Rist, L., Feintrenie, L., \& Levang, P. (2010). The Livelihood Impacts of Oil Palm: Smallholders in Indonesia. Biodiversity and Conservation, 19, 1009-1024. http://dx.doi.org/10.1007/s10531-010-9815-Z

Sasaki, N., \& Yoshimoto, A. (2010). Benefits of Tropical Forest Management under the New Climate Change Agreement: A Case Study in Cambodia. Environmental Science \& Policy, 13, 384-392. http://dx.doi.org/10.1016/j.envsci.2010.04.007

Sandbrook, C., Nelson, F., Adams, W. M., \& Agrawal, A. (2010). Carbon, Forests and the REDD Paradox. Fauna \& Flora International, Oryx, 44, 330-334. http://dx.doi.org/10.1017/S0030605310000475

Sardjono, M. A. (1990). Die Lembo Kultur in Ostkalimantan. Ein Modell fuer die Entwicklung Agroforstlicher Landnutzung in den Feuchtentroppen. Ph.D. Thesis, Hamburg: Universitaet Hamburg.

Sheil, D., Casson, A., Meijaard, E., van Noordwijk, M., Gaskell, J., Sunderland-Groves, J., et al. (2009). The Impacts and Opportunities of Oil Palm in Southeast Asia, What Do We Know and What We Need to Know? Occasional Paper, No. 51, Bogor: Center for International Forest Research. http://www.cifor.org/online-library/browse/view-publication/publication/2792.html

Sikor, T., Stahl, J., Enters, T., Ribot, J. C., Singh, N., Sunderlin, W. D., et al. (2010). REDD-Plus, Forest People’s Right and Nested Climate Governance. Forthcoming in Global Environmental Change, 20, 423-425. http://dx.doi.org/10.1016/j.gloenvcha.2010.04.007

Sofiyuddin, M., Rahmanulloh, A., \& Suyanto, S. (2012). Assessment of Profitability of Land Use Systems in Tanjung Jabung Barat District, Jambi Province, Indonesia. Open Journal of Forestry, 2, 252-256.

http://dx.doi.org/10.4236/ojf.2012.24031 
Terauchi, D. (2011). The Frontier of Oil Palm Production in East Kalimantan. Japanese Journal of International Forest and Forestry, 81, 36-41.

Terauchi, D., Setsuda, T., \& Inoue, M. (2010). Preference of Swiddeners to Rattan, Rubber and Oil Palm: Based on the Evidence from Besiq Village, Indonesia’s Province of East Kalimantan. Journal of Japanese Forest Society, 92, 247-254. http://dx.doi.org/10.4005/jjfs.92.247

Venter, O., Meijaard, E., Possingham, H., Dennis, R., Sheil, D., Wich, S., et al. (2009). Carbon Payments as a Safeguard for Threatened Tropical Mammals. Conservation Letter, 2, 123-129. http://dx.doi.org/10.1111/j.1755-263X.2009.00059.x

Wakker, E. (2005). Greasy Palms: The Social and Ecological Impacts of Large-Scale Oil Palm Plantation Development in Southeast Asia. London: Friends of the Earth. http://www.foe.co.uk/resource/reports/greasy_palms_impacts.pdf

Weinstock, J. A. (1983). Rattan: Ecological Balance in a Borneo Rainforest Swidden. Economic Botany, 37, 58-68. http://dx.doi.org/10.1007/BF02859305

White, D., \& Minang, P. (2011). Estimating the Opportunity Cost of REDD+: A Training Manual. Washington DC: World Bank. http://wbi.worldbank.org/wbi/Data/wbi/wbicms/files/drupal-acquia/wbi/OppCostsREDD+manual.pdf

Yahya, Z. (2011). Aspek Ketenagakerjaan Pengembangan Kelapa Sawit PIR-Swadaya dalam Rangka Pendayagunaan KBNK di Kalimantan Timur. Ph.D. Thesis, Samarinda: University of Mulawarman.

Zen, Z., Barlow, C., \& Gondowarsito, R. (2006). Oil Palm in Indonesia Socio-Economic Improvement: A Review of Option. Oil Palm Industry Economic Journal, 6, 18-29.

Appendix 1. Yield and Price of Fresh Fruit Bunch in Oil Palm Plantation

\begin{tabular}{|c|c|c|c|c|c|c|c|c|c|c|c|c|c|}
\hline \multicolumn{2}{|c|}{ Year of oil palm plantation } & 4 & 5 & 6 & 7 & 8 & 9 & 10 & 11 & 12 & 13 & 14 & 15 \\
\hline \multirow{4}{*}{$\begin{array}{l}\text { Yield } \\
\text { (t/ha) }\end{array}$} & $\begin{array}{l}\text { Mineral soil of } \\
\text { Kalimantan }\end{array}$ & $(15.0)$ & 19.0 & 23.0 & 26.0 & 28.0 & 28.0 & 28.0 & 28.0 & 28.0 & 28.0 & 26.0 & 25.0 \\
\hline & Fertile soil & $(15.0)$ & 18.0 & 21.1 & 26.0 & 30.0 & 31.0 & 31.0 & 31.0 & 31.0 & 31.0 & 30.0 & 27.9 \\
\hline & Infertile soil & $(12.0)$ & 14.5 & 17.0 & 22.0 & 24.5 & 26.0 & 26.0 & 26.0 & 26.0 & 26.0 & 25.0 & 24.5 \\
\hline & Swadaya & 7.6 & 9.2 & 10.0 & 13.0 & 14.6 & 14.6 & 16.1 & 16.3 & 16.3 & 16.3 & 15.0 & 15.0 \\
\hline \multirow{2}{*}{$\begin{array}{c}\text { Price } \\
\text { (IDR/kg) }\end{array}$} & $\begin{array}{l}\text { Average price during } \\
\text { 2008-2011 }\end{array}$ & (1007) & 1080 & 1118 & 1156 & 1193 & 1233 & 1272 & 1272 & 1272 & 1272 & 1272 & 1272 \\
\hline & Price in Swadaya & 600 & 673 & 711 & 750 & 786 & 826 & 865 & 865 & 865 & 865 & 865 & 865 \\
\hline \multicolumn{2}{|c|}{ Year of oil palm plantation } & 16 & 17 & 18 & 19 & 20 & 21 & 22 & 23 & 24 & 25 & \multicolumn{2}{|c|}{ Average } \\
\hline \multirow{4}{*}{$\begin{array}{l}\text { Yield } \\
\text { (t/ha) }\end{array}$} & $\begin{array}{l}\text { Mineral soil of } \\
\text { Kalimantan }\end{array}$ & 24.5 & 24.0 & 23.0 & 23.0 & 22.0 & 21.0 & 20.0 & 19.0 & 18.0 & 17.0 & \multicolumn{2}{|c|}{23.7} \\
\hline & Fertile soil & 27.1 & 26.0 & 24.9 & 24.1 & 23.1 & 21.9 & 19.8 & 18.9 & 18.1 & 17.1 & \multicolumn{2}{|c|}{25.2} \\
\hline & Infertile soil & 23.5 & 22.0 & 21.0 & 20.0 & 19.0 & 18.0 & 17.0 & 16.0 & 15.0 & 14.0 & \multicolumn{2}{|c|}{20.1} \\
\hline & Swadaya & 14.4 & 13.1 & 13.1 & 13.1 & 12.4 & 12.4 & 11.1 & 11.1 & 10.5 & 10.5 & \multicolumn{2}{|c|}{13.0} \\
\hline \multirow{2}{*}{$\begin{array}{c}\text { Price } \\
\text { (IDR/kg) }\end{array}$} & $\begin{array}{c}\text { Average price during } \\
\text { 2008-2010 }\end{array}$ & 1272 & 1272 & 1272 & 1272 & 1272 & 1251 & 1228 & 1186 & 1184 & 1162 & \multicolumn{2}{|c|}{1205} \\
\hline & Price in Swadaya & 865 & 865 & 865 & 865 & 865 & 844 & 821 & 779 & 777 & 755 & \multicolumn{2}{|c|}{811} \\
\hline
\end{tabular}

${ }^{1}$ The data in parentheses are not used in calculation. (Source: The yields in mineral soil of Kalimantan, fertile and infertile soil, and of Swadaya are cited from Pahan (2010), Butler et al. (2009) and Yahya (2011) respectively; The average price during 2008-2011 and price in Swadaya is based on DPPKT (2014), Yahya (2011) and fieldwork). 
Appendix 2. Cost and Benefit of Oil Palm Plantation in Each Type of Development Scheme

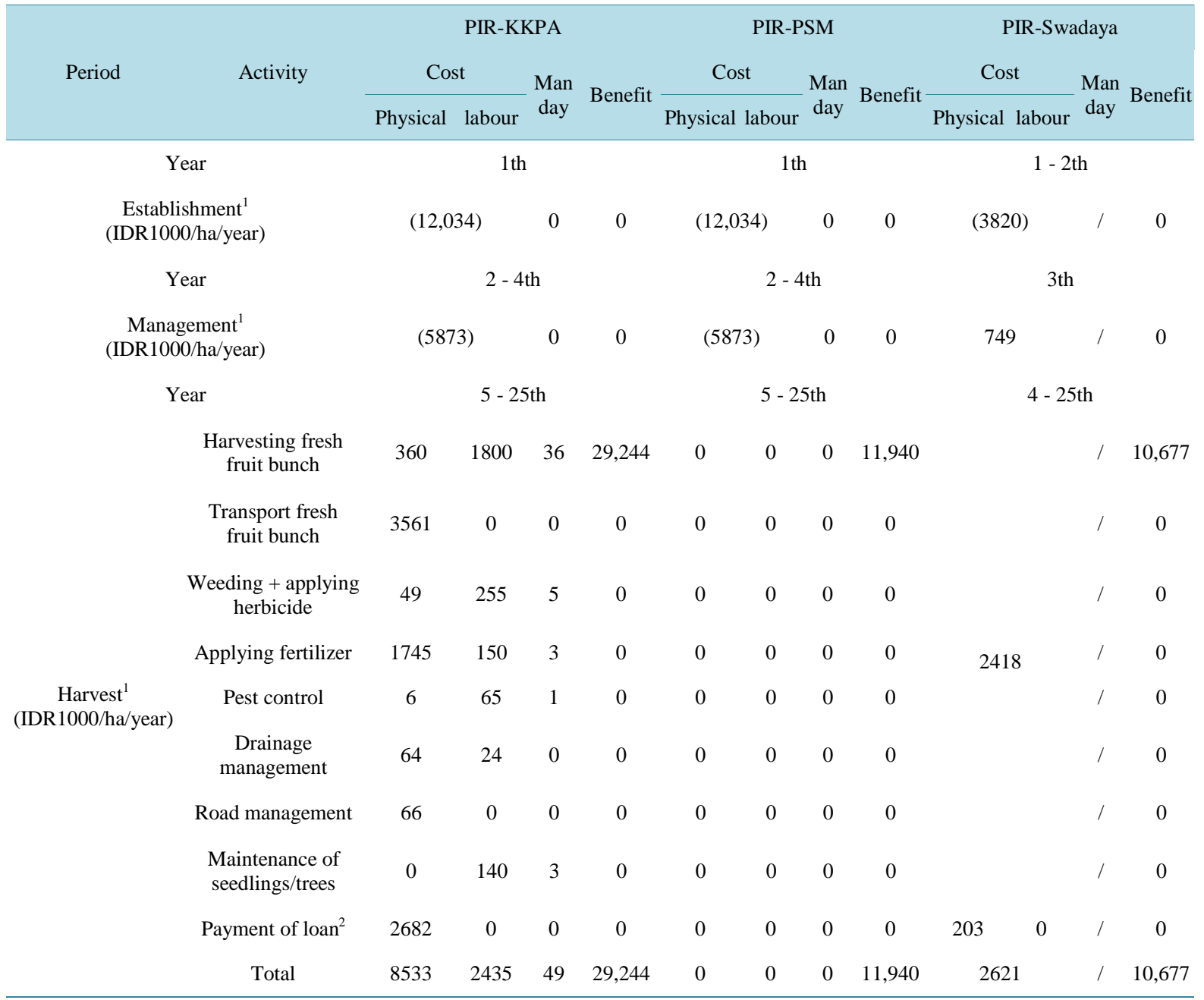

${ }^{1}$ The value of cost and benefit for each period is the average annual value for that period. The benefits (amount of FFB and price) and costs are different in accordance with age of the trees. The costs and benefits of KKPA and PSM in the harvest period are the average case based on the yield of FFB from the mineral soil and the average transportation cost. The value of benefits for PSM shown in this table is villagers' profit, which is distributed by company. The variables of costs of Swadaya could not be referred in Yahya (2011). The cost of establishment and management in parenthesis refers to the offset cost in these periods by project support as grant or loan. ${ }^{2}$ The number of loan payments shown in this table is the total amount of the loan (IDR 56.3 million in KKPA, IDR 4.5 million in Swadaya) divided by the number of harvest period (21 years in KKPA, 22 years in Swadaya). However, the loan will be repaid at approximately IDR 8 million/year during 7 years for KKPA, at approximately IDR 0.75 million/year during 6 years for Swadaya after harvesting begins. (Source: The costs of establishment and management periods and the costs of payment of loan in harvesting period are based on Decree of general director of plantation No.60, 2008 in KKPA and PSM, and based on KP (2010) in Swadaya; The costs of harvesting period except payment of loan in KKPA are based on Pahan (2010) and fieldwork, and in Swadaya based on Yahya (2011); The benefit (yields and price of FFB) in harvesting period is based on Appendix 1.) 


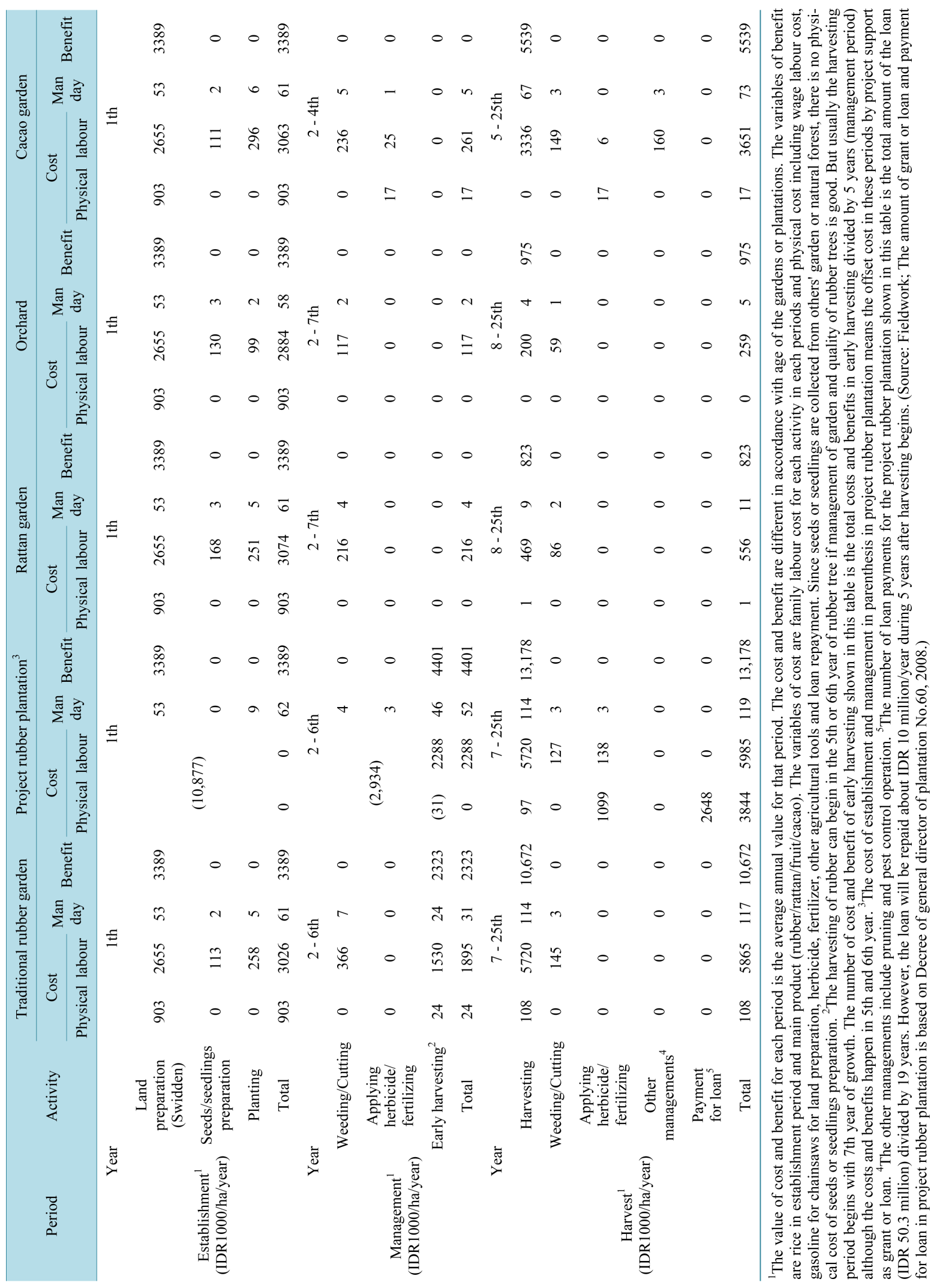

